\title{
Features of application of No-till technology on chernozems of the Central Ciscaucasia
}

\author{
Valeriy S. Tshovrebov ${ }^{1}$, Vera I. Faizova ${ }^{1, *}$, Andrey A. Novikov ${ }^{1}$, Vera $Y$. Lysenko ${ }^{1}$, and \\ Dmitriy $V$. Kalugin ${ }^{1}$ \\ ${ }^{1}$ Stavropol State Agrarian University, Department of Soil science, 355017 Stavropol, Russia
}

\begin{abstract}
Studies were carried out on ordinary carbonate chernozems under winter wheat. No-till technology is applied on more than 200 thousand ha in the Central Ciscaucasia. There are features in the application of this technology related to the composition, properties of chernozems and weather conditions of the territory. An increase in the content of nitrogen (by 20-25 mg kg-1) and phosphorus (by $4-6 \mathrm{mg} \mathrm{kg}^{-1}$ ) in the soil was established as a result of the use of No-till compared to plowing for 5 years. The study revealed an increase in the amount of soil microflora: ammonifiers by 2.5-2.7 times; nitrifying agents by 2.8-3.0 times; nitrogen fixing agents of the genus Azotobacter by 4.5-7.0 times; cellulose-destroying microorganisms by $10-12$ times in a layer of $0-20 \mathrm{~cm}$ of soil. In the seasonal cycle, the largest number of microbes was in the flowering phase of wheat, and the smallest in the spring at the beginning of the growing season. Winter wheat yields during the observation period averaged to $4.61 \mathrm{t} / \mathrm{ha}$ for plowing and increased due to the proposed technology up to $5.34 \mathrm{t} / \mathrm{ha}$. The quality of the products (protein, gluten, grain weight) did not change significantly. Calculations of economic efficiency showed that the level of profitability when using No-till technology is $68-72 \%$, and when plowing it is reduced by $25-30 \%$. Profit from 1 ha was $17-18$ thousand rubles against $8-10$ thousand rubles, respectively
\end{abstract}

\section{Introduction}

Recently, No-till technology has spread in the North Caucasus region. In the Stavropol Territory, about 200 thousand ha is used in this technology [1-2]. Many researchers argue that the use of No-till technology improves the physical properties of soils, water properties, and nutrient content [3-6]. The most significant changes occur in the microbial community. It is argued that this technology is able to increase the number of soil microorganisms and creates a more favorable phytosanitary background [7-8]. Currently, No-till technology is used in many regions of Russia and has both supporters and opponents of its implementation and development. Therefore, the question of its comprehensive study and justification of the need for implementation in various conditions arises especially urgently [9-10].

\footnotetext{
${ }^{*}$ Corresponding author: verafaizova@gmail.com
} 


\section{Materials and methods}

Investigations were carried out in the central part of the Stavropol Territory on ordinary black carbonate medium-heavy low-humus heavy loamy chernozem on loess-like loams. This type of soil is the most common in the Stavropol Territory. The soil contains $3.5-4.0 \%$ humus, 20 - $22 \mathrm{mg} \mathrm{kg}^{-1}$ of mobile phosphorus, 350 - $380 \mathrm{mg} \mathrm{kg-1}$ of exchange potassium, 3, 5 - 4, 5 $\mathrm{mg} \mathrm{kg}-1$ of mobile sulfur. The climate of the research area is characterized by insufficient moisture (420-450 $\mathrm{mm}$ of precipitation per year). The sum of active temperatures is 3000 3200 o, SCC 0.8 - 1.1. No-till technology has been used for 5 years. Field experience was established using plowing and No-till. The size of the plot is 20x40 meters, the repetition is threefold, the sown crop is winter wheat, the predecessor is corn.

\section{Results and discussions}

In the studies, the nitrate nitrogen content was carried out using the potentiometric method, mobile phosphorus according to Machigin in the modification of TsINAO. Productivity was determined by direct combining.

The number of microorganisms was determined by seeding the soil suspension on solid nutrient media. Ashby medium was used for nitrogen-fixing aerobic microorganisms, meatpeptone agar (MPA) was used for ammonifiers, starch-ammonia agar (KAA) for nitrifying agents, and Chapek-Dox medium was used for micromycetes. The number of microorganisms was determined by direct counting of the grown colonies. The result was expressed in colony forming units (CFU) per dry soil weight.

Studies have shown that the content of nitrate nitrogen in the $0-20 \mathrm{~cm}$ layer for plowing during the spring tillering phase was $16.4 \mathrm{mg} \mathrm{kg-1and} \mathrm{increased} \mathrm{by} 12 \mathrm{mg} \mathrm{kg}^{-1}$ according to No-till (table 1).

Table 1. The content of nitrate nitrogen and mobile phosphorus according to the options of the experiment $\left(\mathrm{mg} \mathrm{kg}^{-1}\right)$

\begin{tabular}{|c|c|c|c|c|}
\hline \multirow{2}{*}{$\begin{array}{c}\text { The development } \\
\text { phase }\end{array}$} & \multicolumn{2}{|c|}{$\mathbf{N O}_{3}$} & \multicolumn{2}{c|}{$\mathbf{P}_{\mathbf{2}} \mathbf{O}_{5}$} \\
\cline { 2 - 5 } & tillering & No-till & tillering & No-till \\
\hline Spring tillering & 16.4 & 28.4 & 20.4 & 25.6 \\
\hline flowering & 19.1 & 44.3 & 22.4 & 28.9 \\
\hline Full ripeness & 12.0 & 33.6 & 19.0 & 24.3 \\
\hline
\end{tabular}

The highest values of the studied value were in the flowering phase. In the case of plowing, this indicator was $19.1 \mathrm{mg} \mathrm{kg}$-1and increased 2.5 times in No-till. Therefore, according to this technology, soil microflora is capable of greater accumulation of nitrate nitrogen. In the phase of complete ripeness, the nitrate content was $12 \mathrm{mg} \mathrm{kg}^{-1}$ and increased by $21.6 \mathrm{mg} \mathrm{kg}$-1by direct sowing.

Certain changes were observed in the content of mobile phosphorus. So, in the phase of spring tillering, the content of P2O5 was $20.4 \mathrm{mg} \mathrm{kg}-1$ and increased to $25,6 \mathrm{mg} / \mathrm{kg}$. Similar changes occurred in the flowering phase and in the phase of full ripeness. It can be noted that the highest indices of the content of this nutrient were in the flowering phase.

When taking into account the number of microorganisms of various physiological groups, it was found that the number of aerobic nitrogen fixers of the genus Azotobacter in the spring tillering phase was 56 thousand CFU / $1 \mathrm{~g}$ and slightly increased by 18 thousand CFU / $1 \mathrm{~g}$ using No-till technology (Figure 1). 


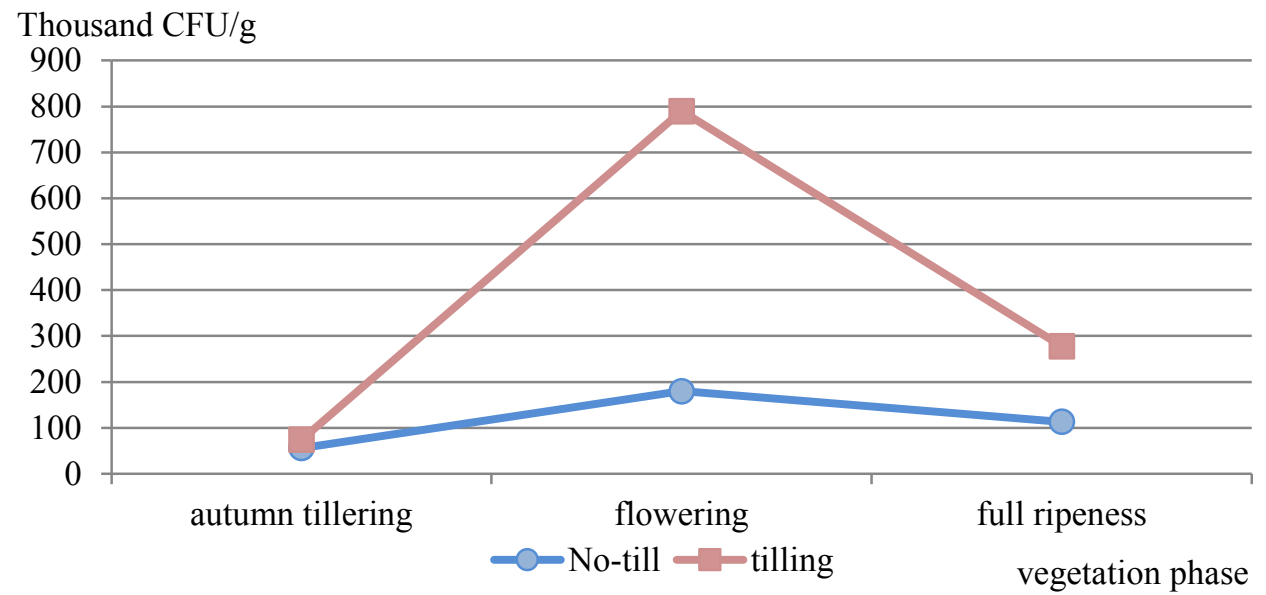

Fig. 1. Seasonal dynamics of the number of aerobic nitrogen fixators under winter wheat using various cultivation technologies $\left(\mathrm{HCP}_{05}=19.6\right)$

In the flowering phase, there was a general increase in the number of this group of microorganisms and the difference between the experimental options. So, the number of nitrogen fixers for plowing was 180 thousand CFU / $1 \mathrm{~g}$ and increased 4.4 times in the direct sowing variant. A similar picture was observed in the phase of complete ripeness, with a general decrease in the number of this group of microorganisms.

Among nitrogen-transforming microflora, ammonifiers occupy a special place. They are able to directly affect the availability of soils with nitrogen and other nutrients. As a result of studies (Figure 2), it was found that on the option of plowing and direct sowing in the phase of spring tillering, the difference in the studied parameter was not found (12 and 14 million CFU / 1 g of soil, respectively).

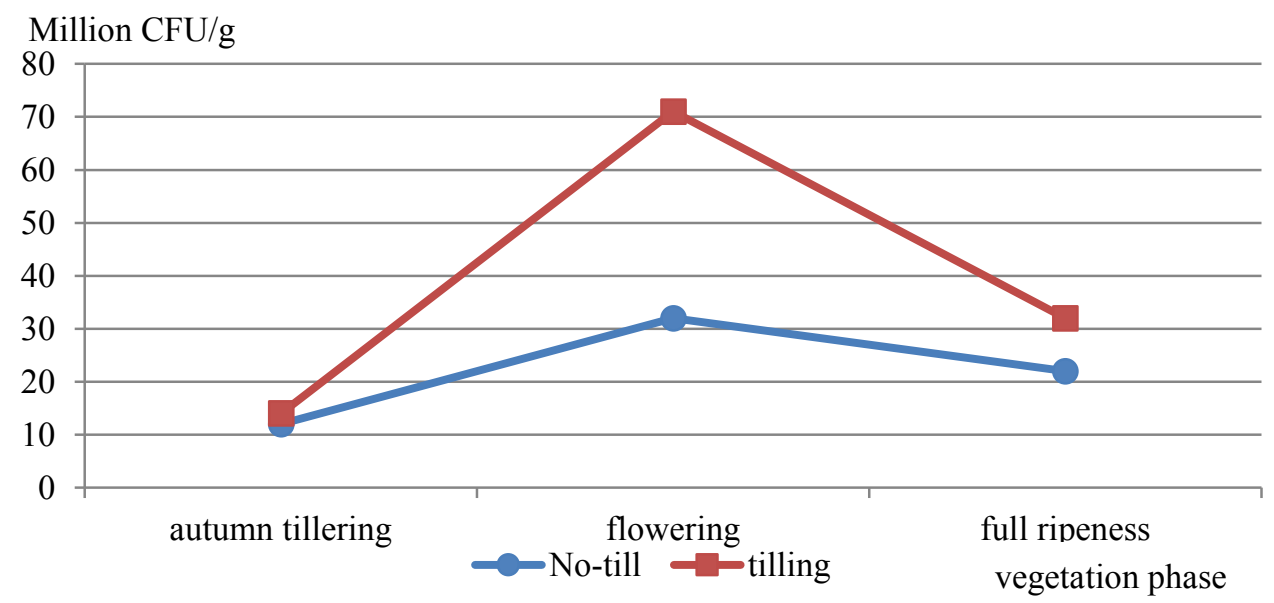

Fig. 2. Seasonal dynamics of the number of ammonifiers under winter wheat by various cultivation technologies $\left(\mathrm{HCP}_{05}=8.4\right)$

During the flowering phase, the number of ammonifiers for plowing increased to 32 million CFU / 1g, and for No-till, to 71 million CFU / 1g. soil, which is 2.2 times higher compared to plowing. In the phase of complete ripeness, a decrease in the studied group of microorganisms occurred while maintaining the difference between the options. 
In direct direct connection with ammonifiers are nitrifying agents. An increase in the activity of ammonifying microflora entails an increase in the activity of nitrifying agents, since there is a close metabolic relationship between them (Figure 3).

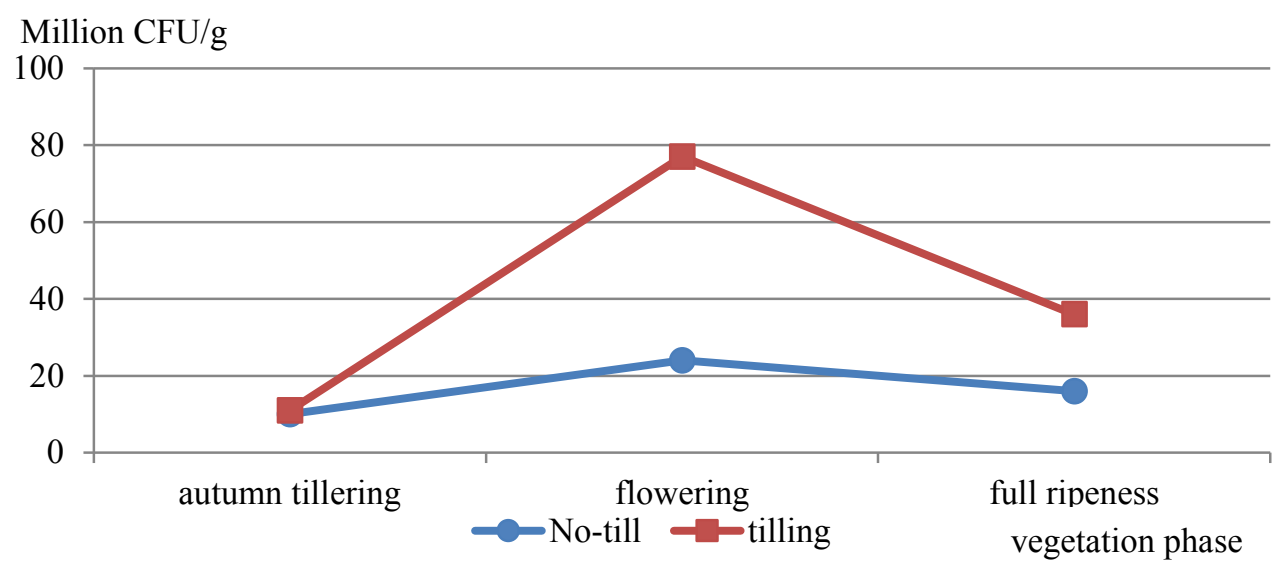

Fig. 3. Seasonal dynamics of the number of microorganisms using mineral forms of nitrogen under winter wheat using various cultivation technologies $\left(\mathrm{HCP}_{05}=9.1\right)$

In the study of the number of microorganisms using mineral forms of nitrogen, a tendency was found in the change in their number similar to the change in the number of microorganisms using organic forms of nitrogen. Thus, the nitrogen-transforming microflora has the ability to increase the number as a result of the use of No-till technology compared to plowing. Most likely, this indicator was affected by an increase in the content of organic matter on the soil surface as a result of the abandonment of plant residues by No-till. In addition, nitrogen fertilizers used fell on organic residues and accelerated the process of their destruction. A close relationship can be observed between the change in the content of nitrate nitrogen in the soil and the change in the amount of nitrogen-transforming microflora.

When examining the number of cellulose-destroying microorganisms, it was found that their smallest number was in the phase of autumn tillering and amounted to 180 thousand CFU / $1 \mathrm{~g}$ for plowing and 205 thousand CFU / $1 \mathrm{~g}$ for No-till (Figure 4).

Thousand CFU / g

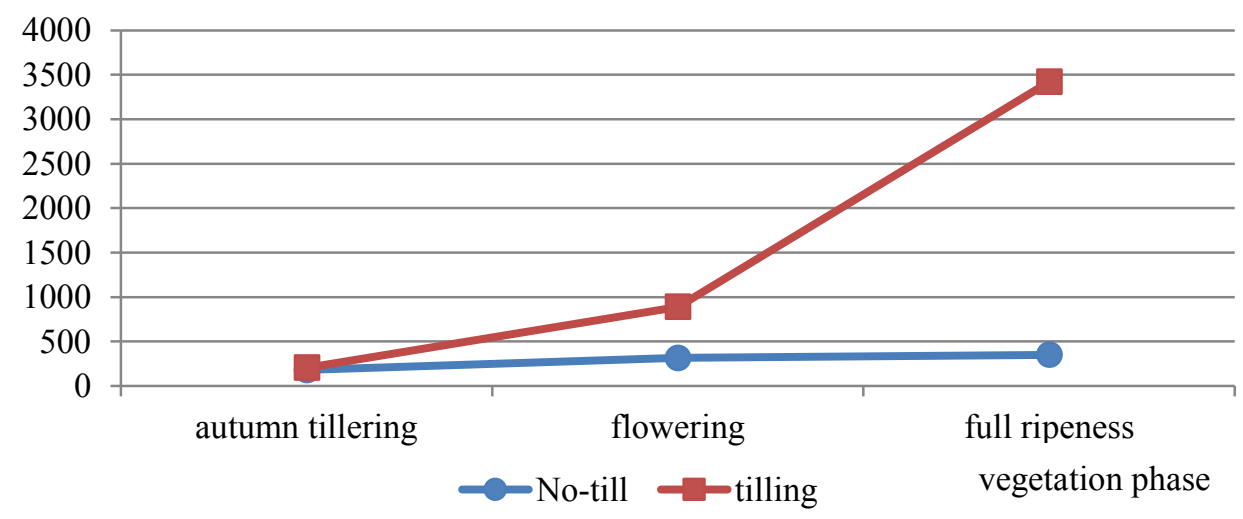

Fig. 4. Seasonal dynamics of the number of cellulose-destroying microorganisms under winter wheat using various cultivation technologies $\left(\mathrm{HCP}_{05}=21.1\right)$ 
The difference between the options is negligible and less than the NDS. In the flowering phase of winter wheat, the number of this group of microorganisms increases by plowing to 316 thousand CFU / 1g and No-till to 890 thousand cfu / 1g, which is 2.7 times higher than the plowing option. The highest number of this group of microorganisms was in the flowering phase of winter wheat. For plowing, this indicator amounted to 351 thousand CFU / $1 \mathrm{~g}$ of soil. As a result of the No-till technology used, the number of this group of microorganisms has increased almost 10 times. A more intense destruction of plant residues can be expected on the direct sowing option.

When studying the number of micromycetes, there was also no difference in this indicator between the experimental variants during the spring tillering phase. This value ranged from 256 - 267 thousand CFU / $1 \mathrm{~g}$ (Figure 5).

Thousand CFU/g

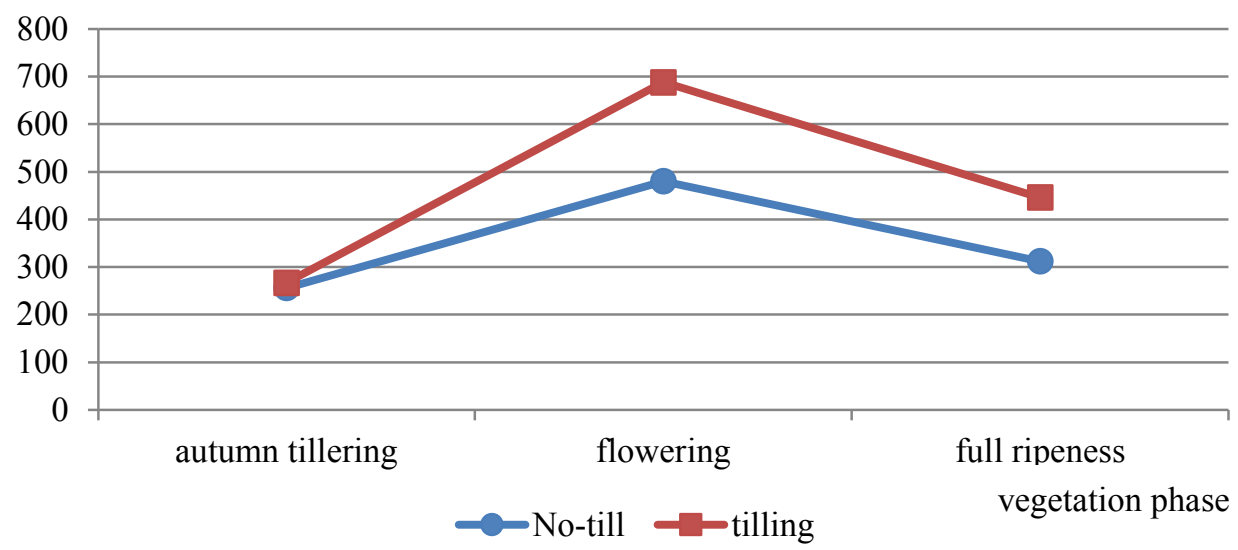

Fig. 5. Seasonal dynamics of the number of micromycetes under winter wheat by various cultivation technologies $\left(\mathrm{HCP}_{05}=16.4\right)$

In the flowering phase, the amount of this group of microorganisms in the plowing variant was already 480 thousand CFU / $1 \mathrm{~g}$. In the No-till variant, the studied indicator is higher by 208 thousand CFU / 1g. In the phase of complete ripeness, there is a slight decrease in the number of micromycetes in both variants of the experiment while maintaining the revealed difference.

When taking into account the productivity of winter wheat, it was revealed that on average for 5 years it was $4.61 \mathrm{t}$ / ha on the plowing option and increased to $5.34 \mathrm{t}$ / ha as a result of the No-till technology. Thus, the difference between the options was $0.73 \mathrm{t} / \mathrm{ha}$.

In the study of the quality of the products obtained, it was found that the content of protein, gluten, grain weight did not significantly change.

Calculations of economic efficiency show that the level of profitability when using Notill technology over the years of research is on average $68-72 \%$, and in the case of plowing it decreases by $25-30 \%$. Profit from 1 ha amounted to $17-18$ thousand rubles against $8-10$ thousand rubles, respectively.

\section{Conclusion}

Thus, the applied No-till technology leads to an increase in the content of nutrients (nitrate nitrogen, mobile phosphorus), to an increase in the number of microorganisms, to an increase in the yield and economic efficiency of winter wheat cultivation. It can be assumed that the technology under study will have distribution in the territory of the Stavropol Territory. 


\section{References}

1. K. Sh. Kazeev, S. I. Kolesnikov, V. F. Valkov, Biologiya pochv yuga Rossii [Soil Biology of the South of Russia] (CVVR, Rostov-on-Don, 2004)

2. K. Sh. Kazeev, S. I. Kolesnikov, V. F. Valkov, Soil Science 7, 848 (1998)

3. V. K. Dridiger, Achievements of science and technology in agro-industrial complex 7, 18 (2012)

4. G. K. Markovskaya, N. A. Kirsyanova, Achievements of science and technology in agroindustrial complex 1, 16 (2007)

5. N. S. Matyuk, V. D. Polin, V. A. Nikolaev, Vladimir agricolist 2, 12 (2015)

6. E. F. Meretskaya, M. M. Demchenko, Zemledelie [Agriculture] 2, 12 (2008)

7. S. A. Pavlov, A. S. Popov, Zernovoe hozyajstvo Rossii [Grain Economy of Russia] 5, 56 (2017)

8. V. I. Titova, A. V. Kozlov, Metody ocenki funkcionirovaniya mikrobocenoza pochvy, uchastvuyushchego $v$ transformacii organicheskogo veshchestva [Methods for assessing the functioning of soil microbiocenosis involved in the transformation of organic matter] (Nizhegorodskaya gosudarstvennaya sel'skohozyajstvennaya akademiya, Nizhny Novgorod, 2012)

9. I. A. Tikhonovich, N. A. Provorov, Agricultural biology 3, 3 (2011)

10. V. S. Tskhovrebov, V. I. Faizova, A. M. Nikiforova, A. A. Novikov, A. N. Marin, Research Journal of Pharmaceutical, Biological and Chemical Sciences 8, 574 (2017) 